Fixed Point Theory, 21(2020), No. 1, 79-92

DOI: $10.24193 /$ fpt-ro.2020.1.06

http://www.math.ubbcluj.ro/ nodeacj/sfptcj.html

\title{
ZERO POINT PRINCIPLE OF BALL-NEAR IDENTITY OPERATORS AND APPLICATIONS TO IMPLICIT OPERATOR PROBLEM
}

\author{
A. BUICĂ ${ }^{*}$, I.A. RUS** AND M.A. ŞERBAN*** \\ * Babeş-Bolyai University, Department of Mathematics \\ 1 M. Kogălniceanu, 400084 Cluj-Napoca, Romania \\ E-mail: abuica@math.ubbcluj.ro \\ **Babeş-Bolyai University, Department of Mathematics \\ 1 M. Kogălniceanu, 400084 Cluj-Napoca, Romania \\ E-mail: iarus@math.ubbcluj.ro \\ ****Babeş-Bolyai University, Department of Mathematics \\ 1 M. Kogălniceanu, 400084 Cluj-Napoca, Romania \\ E-mail: mserban@math.ubbcluj.ro
}

\begin{abstract}
In this paper we give a global zero point principle for operators on a Banach space in terms of ball-near identity operator condition. The techniques of the proof are some variants of the saturated contraction principle. So, we study the well posedness of zero point problem, the Ostrowski property, data dependence and Ulam stability of zero point equations. Some relevant examples are given. Applications to the implicit operator problem are also presented.

Key Words and Phrases: Banach space, ball-near identity operator, saturated contraction principle, zero point principle, well posedness of zero point problem, Ostrowski property, data dependence, Ulam stability of zero point equations, implicit function problem, implicit operator problem.

2010 Mathematics Subject Classification: 47H10, 47J07, 65F10, 26B10, 58C15.
\end{abstract}

\section{REFERENCES}

[1] G.K. Abduvalieva, Fixed point and implicit/inverse function theorem for free noncommutative functions, Ph.D. Thesis, Drexel University, 2015.

[2] M. Altman, Dilating mappings, implicit functions and fixed point theorems in finite-dimensional spaces, Fundamenta Math., 68(1970), 129-141.

[3] J. Appell, Implicit functions, nonlinear integral equations and the measure of noncompactness of the superposition operator, J. Math. Anal. Appl., 83(1981), 251-263.

[4] J. Appell, E. De Pascale, A. Vignoli, Nonlinear Spectral Theory, Walter de Gruyter, Berlin, 2004.

[5] F.V. Atkinson, The reversibility of differentiable mappings, Canad. Math. Bull., 4(1961), no. 2, 161-181.

[6] J.P. Aubin, A. Cellina, Differential Inclusions, Springer, 1984.

[7] R. Bagnara, A unified proof for the convergence of Jacobi and Gauss-Seidel methods, SIAM Review, 37(1995), no. 1, 93-97. 
[8] Z. Balogh, Stability of bijectivity property, Seminar on Fixed Point Theory, Preprint Nr. 3, 1990, $1-12$.

[9] V. Berinde, Şt. Măruşter, I.A. Rus, Saturated contraction principles for nonself operators, generalizations and applications, Filomat, 31(2017), 3391-3406.

[10] J. Blat, On global implicit functions, Nonlinear Anal., 17(1991), no. 10, 947-959.

[11] P.T. Boggs, J.E. Dennis, A stability analysis for perturbed nonlinear iterative methods, Math. Comput., 30(1976), no. 134, 199-215.

[12] K.C. Border, Notes on the implicit function theorem, Caltech, Division of Humanities and Social Scienties, 2016.

[13] F.E. Browder, W.V. Petryshyn, Construction of fixed points of nonlinear mappings in Hilbert space, J. Math. Anal. Appl., 20(1967), no. 2, 197-228.

[14] A. Buică, Strong surjections and nearness, Progress in Nonlinear Differential Equations and Their Applications, Birkhäuser, 40(2000), 55-58.

[15] A. Buică, Principii de Coincidenţă şi Aplicaţii, Presa Univ. Clujeană, Cluj-Napoca, 2001.

[16] S. Campanato, Further contributions to the theory of near mappings, Le Matematiche, 48(1993), 183-187.

[17] M. Cristea, A note on global implicit function theorem, J. Ineq. Pure Appl. Math., 8(2007), no. 3,15 pp.

[18] K. Deimling, Nonlinear Functional Analysis, Springer, 1985.

[19] G. De Marco, G. Giorni, G. Zampieri, Global inversion of function: An introduction, NoDEA, 1(1994), 229-248.

[20] A. Deleanu, Gh. Marinescu, A fixed point theorem and an implicit function theorem in locally convex spaces, (in Russian), Rev. Roum. Math. Pures Appl., 8(1963), 91-99.

[21] J. Dieudonné, Foundations of Modern Analysis, Acad. Press, New York, 1960.

[22] A.L. Dontchev, H. Frankowska, Lyusternik-Graves theorem and fixed points, Proc. Amer. Math. Soc., 139(2011), 521-534.

[23] A.L. Dontchev, A.S. Lewis, R.T. Rockafellar, The radius of metric regularity, Trans. Amer. Math. Soc., 355(2002), no. 2, 493-517.

[24] A.L. Dontchev, R.T. Rockafellar, Implicit Functions and Solution Mappings, Springer, 2014.

[25] P. Ver Eecke, Applications du Calcul Différentiel, Presses Univ. de France, Paris, 1985.

[26] I.G. Fikhtengolts, The Fundamentals of Mathematical Analysis, Vol. 2, Pergamon, 1965.

[27] T.M. Flett, Differential Analysis, Cambridge Univ. Press, London, 1980.

[28] R.S. Hamilton, The inverse function theorem of Nash and Moser, Bull. Amer. Math. Soc., 7(1982), no. 1, 65-222.

[29] M. Hirsch, J. Palis, C. Pugh, M. Shub, Neighborhoods of hyperbolic sets, Inventiones Math., $\mathbf{9}(1970), 121-134$.

[30] D. Idczak, On a generalization of a global implicit function theorem, Adv. Nonlinear Stud., 16(2016), no. 1, 87-94.

[31] M.C. Irwin, Smooth Dynamical Systems, Acad. Press, New York, 1980.

[32] L.V. Kantorovich, G.P. Akilov, Analyse Fonctionnelle, Mir, 1981 (Nauka, 1977).

[33] I.-S. Kim, Fixed points eigenvalues and surjectivity, J. Korean Math. Soc., 45(2008), no. 1, 151-161.

[34] S.G. Kranz, H.R. Parks, The Implicit Function Theorem, Birkhäuser, 2002.

[35] X. Mora, J. Solà-Morales, The singular limit dynamics of semilinear damped wave equation, J. Diff. Eq., 78(1989), 262-307.

[36] L. Nirenberg, Variational and topological methods in nonlinear problems, Bull. Amer. Math. Soc., 4(1981), no. 3, 267-302.

[37] J.M. Ortega, Numerical Analysis, Acad. Press, New York, 1972.

[38] J.M. Ortega, W. Rheinboldt, Iterative Solution of Nonlinear Equations in Several Variables, Acad. Press, New York, 1970.

[39] A. Ostrowski, Solutions of Equations in Euclidean and Banach Spaces, Acad. Press, New York, 1973.

[40] Z. Páles, Inverse and implicit function theorems for nonsmooth maps in Banach spaces, J. Math. Anal. Appl., 209(1997), 202-220. 
[41] N.H. Pavel, Zeros, of Bouligand-Nagumo fields, flow-invariance and the Brouwer fixed point theorem, Libertas Math., 9(1989), 13-36.

[42] A. Petruşel, I.A. Rus, M.A. Serban, Diagonal operators and coupled fixed point via weakly Picard operators technique, Ann. Acad. Rom. Sci. Sec. Math. Appl., 8(2016), no. 2, 155-162.

[43] M. Rădulescu, S. Rădulescu, Application of a global inversion theorem to unique solvability of second order Dirichlet problems, Ann. Univ. Craiova, Math. Comp. Sci., 30(2003), 198-203.

[44] Th. M. Rassias (ed.), Handbook of Functional Equation: Stability Theory, Springer, 2014.

[45] J.W. Robbin, Stable manifolds of semi-hyperbolic fixed points, Ill. J. Math., 15(1970), 595-609.

[46] J.W. Robbin, Hadamard and Perron, Preprint, 1999, 13 pp.

[47] I.A. Rus, Principii şi Aplicaţii ale Teoriei Punctului Fix, Ed. Dacia, Cluj-Napoca, 1979.

[48] I.A. Rus, Results and problems in Ulam stability of operatorial equations and inclusions, In: Th. M. Rassias (ed.), Handbook of Functional Equation: Stability Theory, Springer, 2014, 323-352.

[49] I.A. Rus, Some variants of contraction principles, generalizations and applications, Stud. Univ. Babeş-Bolyai Math., 61(2016), no. 3, 343-358.

[50] I.A. Rus, Relevant classes of weakly Picard operators, An. Univ. Vest Timişoara, Mat.-Inf., 54(2016), no. 2, 3-19.

[51] I.A. Rus, Remarks on a LaSalle conjecture on global asymptotic stability, Fixed Point Theory, $\mathbf{1 7}(2016)$, no. $1,159-172$.

[52] I.A. Rus, F. Aldea, Fixed points, zeros and surjectivity, Stud. Univ. Babeş-Bolyai Math., 45(2000), no. 4, 109-116.

[53] I.A. Rus, A. Petruşel, G. Petruşel, Fixed Point Theory, Cluj Univ. Press, 2008.

[54] I.A. Rus, M.A. Şerban, Basic problems of the metric fixed point theory and the relevance of a metric fixed point theorem, Carpathian J. Math., 29(2013), no. 2, 239-258.

[55] Y. Saad, Iterative Methods for Sparse Linear Systems, SIAM, 2003.

[56] S. Sburlan, Monotone semilinear equations in Hilbert space and applications, Creative Math. Inf., $\mathbf{1 7}(2008)$, no. 2, 32-37.

[57] V. Šeda, Surjectivity of an operator, Czechoslovak Math. J., 40(1990), 46-63.

[58] M.A. Şerban, Teoria Punctului Fix pentru Operatori Definiți pe Produs Cartezian, Presa Univ. Clujeană, Cluj-Napoca, 2002.

[59] M.A. Şerban, Saturated fibre contraction principle, Fixed Point Theory, 18(2017), no. 2, 729740 .

[60] D. Ševčovič, The $C^{1}$ stability of slow manifolds for a system of singularly perturbed evolution equations, Comment. Math. Univ. Carolin., 36(1995), no. 1, 89-107.

[61] P. Smale, A convergent process of price adjustment and global Newton methods, J. Math. Economics, 3(1976), 1-14.

[62] J. Sotomayor, Inversion of smooth mappings, J. Appl. Math. Phys. (ZAMP), 4(1990), no. 1, 306-310.

[63] V. Trenoguine, Analyse Fonctionelle, MIR, Moscou, 1985 (Nauka, 1980; Bucureşti, 1986).

[64] A. Vanderbauwhede, S.A. Van Gils, Center manifold and contractions on a scale of Banach spaces, J. Funct. Anal., 72(1987), 729-740.

[65] G. Wachsmuth, Differentiability of implicit functions, beyond the implicit function theorem, Preprint, Chemnitz Univ. of Technology, Faculty of Math., 2012.

[66] G. Zampieri, Finding domains of invertibility for smooth functions by means of attraction basins, J. Diff. Eq., 104(1993), 11-19.

[67] W. Zhang, S.S. Ge, A global implicit function theorem without initial point and its applications to control of non-affine systems of high dimensions, J. Math. Anal. Appl., 313(2006), 251-261.

Received: March 15, 2018; Accepted: June 7, 2019. 